Article

\title{
Successful Small-Scale Household Relocation after a Millennial Flood Event in Simbach, Germany 2016
}

\author{
Barbara Mayr *, Thomas Thaler@ and Johannes Hübl@ \\ Institute of Mountain Risk Engineering, University of Natural Resources and Life Sciences, \\ Gregor-Mendel-Straße 33, 1180 Vienna, Austria; thomas.thaler@boku.ac.at (T.T.); \\ johannes.huebl@boku.ac.at (J.H.) \\ * Correspondence: mayrbarbara@gmx.at
}

Received: 18 October 2019; Accepted: 28 December 2019; Published: 4 January 2020

check for updates

\begin{abstract}
International and national laws promote stakeholder collaboration and the inclusion of the community in flood risk management (FRM). Currently, relocation as a mitigation strategy against river floods in Central Europe is rarely applied. FRM needs sufficient preparation and engagement for successful implementation of household relocation. This case study deals with the extreme flood event in June 2016 at the Simbach torrent in Bavaria (Germany). The focus lies on the planning process of structural flood defense measures and the small-scale relocation of 11 households. The adaptive planning process started right after the damaging event and was executed in collaboration with authorities and stakeholders of various levels and disciplines while at the same time including the local citizens. Residents were informed early, and personal communication, as well as trust in actors, enhanced the acceptance of decisions. Although technical knowledge was shared and concerns discussed, resident participation in the planning process was restricted. However, the given pre-conditions were found beneficial. In addition, a compensation payment contributed to a successful process. Thus, the study illustrates a positive image of the implementation of the alleviation scheme. Furthermore, preliminary planning activities and precautionary behavior (e.g., natural hazard insurance) were noted as significant factors to enable effective integrated flood risk management (IFRM).
\end{abstract}

Keywords: planned relocation; integrated risk management; collaborative governance; extreme events

\section{Introduction}

Environmental changes and climate change futures clearly challenge policy-makers and societies. While risk in river floods is increasing [1] and flood events are found to be more frequent [2], recent occurrences also cause higher economic losses [3,4]. This is not only due to settlements having developed in recent decades in inundation areas close to rivers, which are now prone to flood risk. Also, augmented wealth of the people and, therefore, higher values of goods at risk contribute to pronounced damages $[5,6]$. Due to a warmer climate, we expect an increase in economic losses caused by hydro-metrological extreme weather events. Consequently, the main political and academic discourse revolves around how we can make our society more resilient for possible future events-not just by introducing smart technical solutions, but also by finding new solutions. In the past decades, various countries around the globe used planned relocation as an option to reduce exposure and vulnerability to future catastrophes [7-9]. However, these examples constitute exceptional cases in present-day flood risk management (FRM) policy and practice, as the planned relocation of individuals, businesses, and infrastructure is largely ignored as a possible strategy in the various national FRM policies across the world. Relocation from areas at risk is a rather uncommon adaptive measure. Affected households must deal with multiple long-term impacts on their livelihoods and might even 
create new vulnerabilities [10-17]. Planned relocation will become a more important flood and coastal risk management strategy in response to the current challenges of climate-driven hazards and their associated negative consequences like sea level rise or increasing adverse consequences of weather extremes. It might be that more than 140 million people have to relocate by 2050 because of flooding, food or water shortage, and economic reasons [18]. This raises the question of how to organize planned relocation instead of uncontrolled or unplanned relocation $[13,19]$.

Successful implementation of planned relocation should include a wide engagement process with citizens [10], which is a central objective in European directives such as the European Floods Directive (EU FD) [20] or Water Framework Directive (WFD) [21]. While this is implemented in Germany and Bavaria by national laws, innovative and collaborative approaches need to include burden and responsibility sharing amongst different disciplines and actors of various levels. Herewith, the financial aspect and accountabilities of responsible sectors, as well as inter- and trans-disciplinary cooperation of several fields and policy areas, such as spatial planning, water management, and local building regulations, need to be considered. This requires the involvement of private businesses and the insurance sector.

The present study deals with the extreme flood event at the Simbach torrent in Germany, which happened on 1 June 2016. The causes of the flooding were continuous heavy rainfall in the catchment area, which lasted several days, together with a failure of structural measures. As a result, the flood inundated parts of the Simbach township and caused five fatalities [22]. During the event, thousands of people were evacuated. Afterward, some of the residents were not allowed to enter their homes for some days due to severe damage of the buildings. Finally, homeowners near the river were relocated. The relocation was necessary because of the increased area demand, which was needed for an adapted structural alleviation scheme at the riverside near the city center. Decisions about purchasing and demolishing properties located in this area were made early by the responsible authorities. Hence, the officials entered into dialogue with affected homeowners at the beginning of the planning process after the event happened. Residents were, therefore, informed quite early and were later on offered financial compensation for their property based on an independent appraisal. Relocation is voluntary by law; for some, however, no other option remained than moving away as rebuilding in the same zone was precluded.

Specifically, the paper deals with main goals and strategies in the planning and implementation of flood risk mitigation measures and the relocation of 11 households. It describes the interactions between authorities, administrators, and affected citizens during the overall process. In this way, several aspects such as collaborative governance, the inclusion of public administration, and the public, as well as risk communication, contributed to the success and the acceptance of decisions, particularly in consideration of the relocation. The term "stakeholders" includes involved/affected citizens, local administrative, governmental actors, planners, and experts. Altogether, these comprise people who are responsible for the flood risk mitigation process and measures, as well as citizens, who are directly and indirectly affected by the consequences of the flood. Therefore, the study is based on the following question: "How can flood risk mitigation strategies, in particular small-scale relocation of communities, be successful?"

\section{Literature Review}

\subsection{Planned Relocation in Flood Risk Management}

The EU FD prescribes the assessment of hazardous areas from surface waters through hazard and risk maps, which have to be implemented on national and local levels of member states to prevent future flood damage [20]. Therefore, "a balanced combination of measures on the river itself, in the catchment area, and in the flood risk areas" is recommended (p. 111) [23]. Dieperink et al. [24] investigated national FRM strategies in Europe and identified main governance challenges resulting from diversified strategic goals. These are as follows: prevention, aiming at risk reduction by lowering 
the exposure of people and properties; defense, linked to protection by structural measures and the reduced probability of flooding; and mitigation, to decrease the vulnerability of areas and people prone to risk. In addition, individual preparation and recovery solutions including reconstruction and compensation are mentioned [24]. While strategies can supplement each other, their coordination needs to include "multi-actor, multi-level, and multi-sector involvement" (p. 4475) [24] and is realized for example by collaborative leadership. Stakeholder and community involvement, defined roles and responsibilities, and a common knowledge basis are also fundamental [24]. Hartmann and Albrecht (2014) determined a shift from a structural approach of flood protection to a more holistic risk management in Europe [25]. While integrated flood risk management (IFRM) in European countries targets similar action fields, prevention, protection/mitigation, and preparedness are revealed as applied key strategies. Furthermore, preventive planning and individual precautionary measures serve the reduction of risk, vulnerability, and exposure. Adaptive actions before a disaster also leave sufficient time for their implementation. Nonetheless, IFRM also needs to be aligned with environmental goals. The combination of active and passive mitigation is, therefore, often considered as an appropriate approach to face flood risk. Kundzewicz (2002) stated that non-structural measures are seen as beneficial supplements to technical constructions and claimed that they "are in better agreement with the spirit of sustainable development, being more reversible, commonly acceptable, and environment-friendly" (p.3) [26]. Kreibich et al. (2017) recommended engaging land-use planning and its regulations to reduce exposure, even though efforts will only be revealed in the long run $[27,28]$. In addition, non-structural measures also address shortcomings in public risk perception, awareness, and education [29].

One solution to extreme weather events is planned relocation. A planned relocation is defined by the United Nations High Commissioner for Refugees (UNHCR) in the context of migration in developing countries and environmental change as "a planned process in which persons or groups of persons move or are assisted to move away from their homes or places of temporary residence [ ... ] to protect people from risks and impacts related to disasters and environmental change, including the effects of climate change" [30]. Therefore, the given time to plan such a process is a key factor. A relocation during the aftermath of a disaster needs to be executed under time pressure and does not allow sufficient time for preparation. Planned relocation of communities, groups, or individuals can be implemented appropriately, as long as certain aspects are considered [30]. In the United States (US), planned relocation is an effective strategy to overcome global changes via land use and regional planning principles-especially with regard to climate change adaption [31-33]. Nevertheless, relocation causes intensive social and economic impacts to individual well-being and socio-economic performances [9,14-16,28,34]. The term relocation is also commonly used in European and international FRM literature $[9,12,13,35]$. Yet, in contrast to other parts of the world, large-scale relocation is rarely applied in Central Europe. In democracies, relocation takes place on a voluntary basis, whereby support from the government, federal state, and local authorities is requested, not least because of the costs. Relocation is an alternative to expensive structural measures, in particular when the renovation of damaged buildings and properties is not feasible due to substantial damage. However, there is no legal foundation for a long-term evacuation from flood-prone areas including Austria [36]. While governments make main decisions based on water management planning, risk assessments, and spatial development plans, it is the responsibility of municipal actors and local administration to keep areas at risk free from development at the communal level. Mayor, city councilors, and administrators are considered as central authorities with regard to the interaction with the affected community, whereby four levels of involved actors are defined: "public administration on national, federal state, and communal levels, and additionally non-governmental actors (social organizations, disaster control, media, and neighbors)" (p. 5) [37]. Long-term benefits of relocation in reducing risk of loss and saving costs are the main argument for relocation, while challenges are "financial issues, project management and communication, delimitation of relocation zones, exchange properties, and keeping free relocated areas from buildings" (p. 9) [37]. One crucial aspect of community protection is that the remaining risk areas, originally protected behind structural measures, are prone to higher 
risk, if the flood event exceeds the protection level of the technical constructions [23]. This needs to be included as a key message in risk communication with affected communities.

\subsection{Collaborative Governance and Stakeholder Engagement}

The term governance originates from government, characterized by Stoker (1998) as "formal institutions, resources of the state, and their monopoly of legitimate coercive power" including decision-making power and national processes (p. 1) [38]. Governance is a structural framework providing the basis for collective actions while shifting power and responsibility to members of the civil society. The idea is based on collaborating actors and networks sharing common goals and visions. The close collaboration of governmental and non-governmental actors can foster increased acceptance of top-down decisions and their outcomes amongst the policy-affected community. Public and private actors, as well as third sector organizations like interest groups, are thereby involved [38,39]. Ansell and Gash (2008) defined a collaborative government as follows: "a governing arrangement where one or more public agencies directly engage non-state stakeholders in a collective decision-making process that is formal, consensus-oriented, and deliberative and that aims to make or implement public policy or manage public programs or assets" (p. 544) [40]. The governance approach assigns less power to the central state authority and more to the community, where resources, purposes, and visions are shared in interactive networks $[38,39]$. While the process outcome is more important than the process itself [39], there are also limits to governance. Participation in policy processes does not only require resources like money and time; knowledge and information are also prerequisites for taking part in policy- and decision-making. If knowledge is not provided, this can hinder engagement [39].

Flood risk governance [41] promotes inclusive collaboration and governance approaches comprising all stakeholders in the decision-making process. This is actively recommended by international policies and national documents (for example, the EU Floods Directive, 2007). Governments and ministries are responsible for the national implementation of water management and FRM legislation in their national states according to European regulations. Central state authorities are, therefore, the main actors in the coordination and planning of risk mitigation measures at a national level. These actors have executive power, e.g., in decision- and policy-making about financial funding of flood damage. Regional and local stakeholders are dependent on their decisions. In a collaborative governance approach, power and responsibility are shared. Thus, instead of top-down structures, stakeholder engagement and public participation lead to flatter hierarchies and the horizontal distribution of responsibility and duties. This enhances the acceptance of decisions and process outcomes, as the communities' needs and interests are increasingly acknowledged. However, coordination and regulation on a local level are needed, especially in those areas where spatial planning visions, risk management interest, and individual purposes are divergent. Planned relocation and its implementation, therefore, need a collaborative process and the engagement of various stakeholder at different levels [34].

\subsection{Stakeholder Engagement in Planned Relocation}

Integral flood risk management is a main topic of the Bavarian State Ministry for the Environment and Consumer Protection and is outlined in the Action Program 2020plus [42], describing an holistic approach to reduce flood risk in communities. How several policy fields, laws, and regulations in Germany and Bavaria are involved in FRM is shown in Appendix A. The inclusion of main stakeholders in environmental policy- and decision-making is crucial, as it can enhance legitimacy and the social acceptance of the process outcome [43]. Successful FRM, therefore, requires a high level of integration and coordination of agencies and stakeholders.

Conflicts of usage between owner and the public interest can hinder land-use change or regulatory constraints in flood-prone areas. This requires serious integration of affected parties; in addition, effective building restrictions by local policies and the re-dedication of building land in "green fields" are demanded [44]. As it is unsustainable to inhabit areas prone to flood risk, in Australia, the responsibility 
of buying at-risk areas or properties and, consequently, the provision of alternative retreats are assigned to governments and regional authorities [45]. There is also a pre-emptive right assigned to the state authorities in Bavaria to purchase flood-prone areas [46]. Buyouts are defined as "form of property acquisition in which houses and lots are purchased from willing sellers with the land restored to natural open space in perpetuity", and they work best when "initiated and organized at the grassroots level" (p. 61) [47].

Relocation is often implemented post occurrence, as the urgency is not obvious in "peace times". Thus, the elaboration of preliminary plans and having a strategy available in the early stage of the disaster aftermath can help to anticipate crisis after catastrophes. Thus, instead of implementing disaster-driven measures after a flood event, for example, in the United Kingdom (UK), it is suggested to recognize "signals" prior to natural hazards and to act accordingly [48]. Unlike "unplanned or reactive adaptation", this acting encourages "being able to take a more proactive and strategic approach" (p. 14) [48]. However, there is a trend to enforce buyouts as a preventive risk mitigation measure, although funding is mainly available after hazardous events; the window of opportunity refers to a higher acceptance of mitigation measures when implemented directly after a disaster [34], which can raise the willingness to accept relocation. Nevertheless, climate change adaptation regarding FRM needs to involve prior planning and integrated planning visions. This will be even more significant in the future. In addition, the opportunity to professionally accompany a relocation process needs to be provided and communicated to the affected people [34].

\section{Materials and Methods}

\subsection{Case Study}

Simbach at the Inn (Simbach a. Inn) is located in the district Rottal-Inn in the southern part of Lower Bavaria (Niederbayern), an administrative district of the Free State Bavaria in Germany (see Figure 1). The township counts around 9800 inhabitants, is located at $346 \mathrm{~m}$ above sea level, and has an area of $4733 \mathrm{ha}$. The Simbach torrent leads to the Inn, which is a river at the Austrian border. With a length of $0.92 \mathrm{~km}$ and a catchment area of $33.00 \mathrm{~km}^{2}$, the mean flood discharge of the channel is $10.2 \mathrm{~m}^{3} / \mathrm{s}$. The Simbach belongs to the planning section of the Water Management Agency (WMA) Deggendorf and is classified as a surface water with potentially significant flood risk [49]. Flood events at this torrent occurred for decades [50,51]; first events were registered in 1661-1663. The Simbach was flooded every 10 years in the 18th century. Mentionable events occurred in 1938, 1954, 1991, 1999, and 2013. Seven out of 25 investigated floods at the Simbach were caused by continuous heavy rainfall, and a further 12 events were triggered by increased water levels of the Simbach and the Inn $[50,52,53]$.

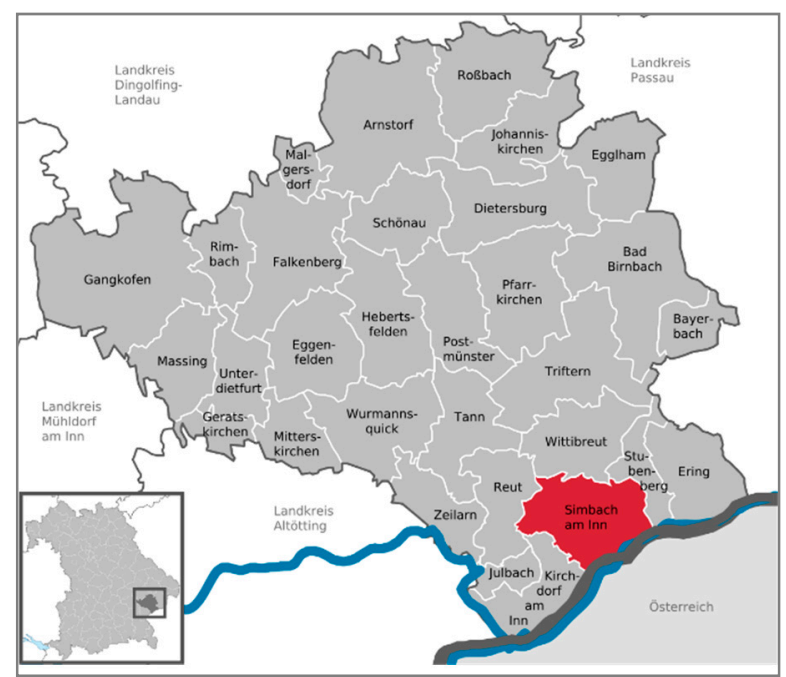

Figure 1. Location Simbach at the Inn in Bavaria, Germany (Source: https://goo.gl/images/w8KDTs, 15 December 2019). 
The successful planning and implementation of flood risk mitigation in Simbach including household relocations is investigated by a single case study. Relocation was necessary, after a flood exceeding a 100-year design event at the Simbach torrent in Bavaria (Germany) in 2016 hit and destroyed parts of the town including infrastructure, buildings, and land. The millennial flood event (a 1000-year or millennial flood event has a probability of one in 1000 years. The statistical probability for occurrence is 0.1 per year) claimed five victims and made around 1000 people homeless [54]. It occurred on 1 June 2016, and it was triggered by continuing heavy rainfall in the catchment area. While the calculated rainfall was $183.50 \mathrm{~mm}$ of precipitation, the combination of hydrological unfavorable meteorological conditions influenced by specific characteristics of the area led to the damaging flood event [55]. The natural peak discharge at the Simbach is $180 \mathrm{~m}^{3} / \mathrm{s}$, and the maximum discharge during the event was estimated at $280 \mathrm{~m}^{3} / \mathrm{s}$. A breakdown of a road embankment amplified the situation [56,57]. The failure of structural measures contributed to increased damage, and an area of $1.7 \mathrm{~km}^{2}$ in the township was inundated [22].

The elaborated risk reduction scheme, including an improved protection level for the community after the disaster, conditioned the household relocation. The mitigation concept was planned based on technical and scientific facts of the event documentation and analysis [55,57]. A basic value in the concept is the newly calculated discharge volume of the channel based on a design event of the return interval of 1:100, which is $115 \mathrm{~m}^{3} / \mathrm{s}$ (plus freeboard of $30 \mathrm{~m}^{3} / \mathrm{s}$ ). This value was nearly doubled compared to before [57,58] (Interview 5, 2018).

\subsection{Data Collection and Analysis}

The case study approach after Yin $(2012,1994)$ was found appropriate to investigate the extreme flood event in Simbach, showing a single and rare occasion [59,60]. "A case study is an empirical inquiry that investigates a contemporary phenomenon within its real-life context, especially when the boundaries between phenomenon and context are not clearly evident" (p. 13) [60]. A single case study can confirm but also demand alternatives or further explanations for theoretical propositions. This is how it contributes to knowledge generation and theory-building. The method allows an in-depth look with a revelatory explanations about a social phenomenon, while being applied to analyze unique events $[60,61]$. In this way, in-depth descriptions aim to facilitate deeper understanding of a case [62]. Another benefit is the possible generalization of the results to other situations or theories [59,60]. Flyvbjerg (2006) stressed that the option to "allow the study to be different things to different people" is an advantage of the case study and added that "a purely descriptive, phenomenological case study [ . . . can certainly be of value" (p. 10) [63]. The case study method serves to analyze interactions and the collaboration between stakeholders, while it assesses "how" and "why" questions (e.g., how the process was, why the outcome was accepted).

Seven semi-structured expert interviews were conducted with stakeholders like governmental actors, local politicians, planners, and scientists, as well as with two affected residents. Interviewees were selected according to the idea of snowball sampling, which is an approach developed by Goodman (1960). Based on a random sample of individuals at the beginning of the investigation, those people are asked to name additional persons concerned with the research issue. Then, these are ask to recommend other people and so on [64]. Also named chain-referral sampling, this technique is "used to locate, access, and involve people from specific populations in cases where the researcher anticipates difficulties in creating a representative sample of the research population" (p. 427) [65]. Additional aspects for the selection of interview partners were professional field, levels, hierarchies, and general involvement in the planning process. Individual conversations on the spot during the site visits enriched the researchers' perspectives and enhanced understanding for the issue. While the transcribed documents-together with protocols and one observation of a citizen assembly—served as multiple sources of evidence [60], additionally, over 100 media articles were used. These were mainly articles and reports from local newspapers such as the Passauer Neue Presse (www.pnp.de) and the Süddeutsche Zeitung (www.sueddeutsche.de). Insights based on press releases from the Bavarian State Ministry for the Environment and Consumer Protection (STMUV) and an illustrated book about the flood event [50] contributed to the investigation. 
Grounded theory was used for the analysis of the transcribed documents; by coding and categorization, main concepts were developed on the essential issues [66]. Grounded theory allows the systematic analysis of qualitative data by categorizing and coding. Transcription of the recorded interviews in a first step is a process of abstraction [67] to make the data available for the analysis. Codes are developed with reference to the research questions or statements, and they serve to structure the data. While relevant text passages are marked with keywords, these codes reveal patterns and relationships between elaborated categories and thematic concepts, which are the basic unit for the analysis. "The procedures of grounded theory are designed to develop a well-integrated set of concepts that provide a thorough theoretical explanation of social phenomena under study" (p. 5) [66]. Consequently, the aim is to elaborate a theory based on categories, which is "grounded" in the data. Therefore, the analysis and data collection are not a linear process, but they interfere [68], and the relationship between researcher and data should be a creative interplay [66]. The researcher needs to stay open to new categories and topics since these are adapted as the research proceeds. Since the theoretical statements were derived from literature at the beginning, the corroboration of arguments for and the generalization of those propositions by the findings were targeted during the investigation [60]. Interviews and site visits, as well as the collection of media documents took place from December 2017 to November 2018. The output of this investigation provides guidance for politicians and administration. It raises awareness and understanding for risk mitigation and gives empirical information about planned relocation, while those insights can be applied in similar processes.

\section{Results}

\subsection{Responsibilities and Collaboration in Planned Relocation Process}

Actors and stakeholders involved in FRM and their assigned roles in the Simbach process are depicted in Table 1. This is based on an illustration of the Bavarian State Ministry for the Environment and Consumer Protection (STMUV) (2014), augmented with relevant information gained during the interviews in 2018.

As the Simbach torrent is a developed creek in the city center, it is categorized as a surface water of third order according to the German river classification system. Therefore, the authority and the responsibility of maintenance and constructions on the channel fall on the Bavarian State. The goal in Simbach after the flood event was to improve flood protection by expanded structural measures according to a newly calculated design event. Consequently, the planning and implementation process included the relocation of dykes based on the enlargement of the torrents' cross-section following the calculation of an increased floodwater discharge volume of $115 \mathrm{~m}^{3} / \mathrm{s}$. While this new value was adapted and calculated based on time series of yearly discharge maxima of the channel in recent decades, it determines the size and height of the structural measures. The improved mitigation scheme included the reconstruction and relocation of existing dykes, and newly built structural measures such as dykes and walls $[55,57]$. This includes a factor of $15 \%$ for climate change adaption at new flood defense constructions in Bavaria, which was introduced in 2004 [49]. At the mitigation concept at the Simbach torrent, this factor corresponds to an additional discharge volume of $14 \mathrm{~m}^{3} / \mathrm{s}$, while the overall discharge is calculated at $115 \mathrm{~m}^{3} / \mathrm{s}$ [69-71].

The requirement to build improved flood defense structures and the need for property relocation was evident after the damaging event. A decision about the required area was made in the early phase of the (re-)construction and planning process, mainly by an estimation based on the expertise and experience of involved planners of the responsible Water Management Agency (WMA) and, consequently, the definition of an "approximate corridor" (Interview 5, 2018). These planned structural measures required the governmental buyout and destruction of 11 properties at the riverbanks, as well as the purchase of further land slots. Nonetheless, a second goal evolved in the local community; the vision was the redesign of the riverine area in the city center as a green space, and the opportunity to build a new recreational area near the city center was used. This was initiated by the municipal actors on 
a local level in Simbach. The design was harmonized with the risk reduction scheme, and consequently challenged water management, landscape planners, and engineers during the collaborative planning process. While each party in the process represented and advocated their own interest by maximizing the area or benefits within the given boundaries, negotiations on details between planners of different disciplines (e.g., landscape and water management) and also property owners and authorities were sometimes long-lasting. Additionally, the overall planning process took more than two years, which was criticized by the community. Nonetheless, the design of the common recreation area had to follow the plans of the alleviation scheme as the main goal.

Table 1. Actors and responsibilities in flood risk management (FRM) and the planning process.

\begin{tabular}{|c|c|}
\hline Actors and Authorities & General Responsibilities/Tasks in the Simbach Project \\
\hline 1. Bavaria & $\begin{array}{l}\text { - The state of Bavaria is the project carrier in Simbach. } \\
\text { - The government and ministries are responsible for maintenance, } \\
\text { development, and funding. }\end{array}$ \\
\hline $\begin{array}{l}\text { 2. Bavarian State Ministry for } \\
\text { the Environment and } \\
\text { Consumer Protection (STMUV) }\end{array}$ & $\begin{array}{l}\text { - } \quad \text { Responsible for the overall strategy for FRM. } \\
\text { - } \quad \text { Financial management of investments, maintenance, and funding. }\end{array}$ \\
\hline 3. Federal governments & $\begin{array}{l}\text { - Steering and coordination of flood risk mitigation activities on a } \\
\text { federal district level (like Niederbayern for the Simbach). There are } \\
17 \text { administrative regions in Bavaria. }\end{array}$ \\
\hline $\begin{array}{l}\text { 4. Bavarian Environment } \\
\text { Agency (LfU) }\end{array}$ & $\begin{array}{l}\text { - Development of strategic and technical basics. } \\
\text { - } \quad \text { Consultancy of water management authorities. } \\
\text { - The LfU is the advisory authority for the ministry at the local level and } \\
\text { collaborated with the WMA. }\end{array}$ \\
\hline $\begin{array}{l}\text { 5. Water Management Agency } \\
\text { (WMA Deggendorf) }\end{array}$ & $\begin{array}{l}\text { - Main tasks are planning, realization, and maintenance of natural and } \\
\text { structural measures, as well as the construction of mitigation measures } \\
\text { while representing the state (1st- and 2nd-order water bodies } \\
\text { and torrents). } \\
\text { - Funding of measures on } 3^{\text {rd }} \text {-order waters. } \\
\text { - Official technical experts in subjects dealing with floods initiated the } \\
\text { relocation in Simbach. } \\
\text { - Communication and negotiation with the residents. } \\
\text { The real estate department was involved in the communication during } \\
\text { the property and area buyout process. }\end{array}$ \\
\hline $\begin{array}{l}\text { 6. District administration } \\
\text { authorities (Rottal-Inn) }\end{array}$ & $\begin{array}{l}\text { - Dealing with water legislation procedures. } \\
\text { Dedication of inundation areas in accordance with spatial } \\
\text { development goals. } \\
\text { - Preparation and lead in the emergency case. }\end{array}$ \\
\hline 7. Cities and municipalities & $\begin{array}{l}\text { - Municipalities in general contribute to the funding of the new } \\
\text { measures, as they are the benefitting parties. } \\
\text { - } \quad \text { Construction of flood risk mitigation measures on waters of 3rd order. } \\
\text { - Flood notifications to community and hazard defense. }\end{array}$ \\
\hline $\begin{array}{l}\text { 8. General public and affected } \\
\text { residents }\end{array}$ & $\begin{array}{l}\text { - } \quad \text { Participation and information, individual negotiations. } \\
\text { - } \quad \text { Workshops/round tables, risk communication. } \\
\text { - } \quad \text { Affected by relocation and area buyout. }\end{array}$ \\
\hline
\end{tabular}

The WMA was responsible for planning the technical measures and initiated the property relocation. In collaboration and with consultation from the Environment Agency (Landesamt für Umwelt-LfU) it planned the construction activities at the Simbach on behalf of and in the interest of the project carrier, the Bavarian state. The WMA Deggendorf is located in the water district and planning section Rottal-Inn (administrative district Niederbayern). However, only with respect to the main 
priority of flood risk reduction and improved protection of the community, "the municipality or city has the possibilities to design the inner area" (Interview 3, 2018). To interlock the urban plans of the WMA and the communal authorities was a main challenge. "This needs a lot of energy and meetings [ ... ] to get to the same initial basis. But the cooperation does in fact work very well, only with a few exceptions, sometimes you just talked at crossed purposes, but this can be learned" (Interview 3, 2018). Meetings enabled interdisciplinary learning, and while misunderstandings had to be eliminated, negotiations and discussions between stakeholders were crucial components in the adaption of the planning concepts. While all the steps in a planning process are interconnected, permanent changes require a consensual dialogue and solutions. Flood risk reduction, therefore, was always the leading priority (Interview 5, 2018).

Decision-making and implementation mainly took place on two levels: (1) the regional level, where the WMA and district authorities had main responsibility in the planning process representing the Bavarian State, and (2) the local level, where actors like the mayor and the city administration designed the recreational area together with representatives of specific planning disciplines. Local stakeholders were also responsible for intervening in the detailed concepts (flood risk reduction and design of riverine area) in coordination with the technical planner and the head of the WMA as main contacts: "[ ... ] the task is to bring those parties to cooperation without smashing heads" (Interview 3, 2018). The planning process was largely organized in a top-down manner, such as design and approval of the local FRM strategy, compensation scheme, and payment. Hence, main challenges during the collaboration did not evolve when planning the mitigation scheme, but rather within the detailed planning and the accordance with the design of the riverine areas. However, the planning process needed to be transparent and concepts could not be elaborated "behind closed doors [ ... ] these days" (Interview 5, 2018). It was also emphasized that integration is limited by restricted knowledge of citizens and by the general capacity to include individual ideas in technical plans. Nevertheless, minor interest conflicts (equipment, plants, and infrastructure in the riverine area) were collaboratively solved, with the main aim and the commonly pursued goal of risk reduction in mind.

\subsection{Process of Planned Relocation in Simbach}

While the moving of residents and properties in Bavaria is usually supported by a compensation payment of $65 \%$ of the property value, the government additionally pays the deconstruction costs, and the land is left with the owner. From 1965 until 2013, 32 million euros were invested in the dismantling of developed areas in inundation land in Bavaria [72]. While available governmental funding is a precondition for buyouts and planned relocation, the willingness to participate in the process on behalf of the affected community is essential [45]. Compensation payments are considered as important financial incentives, while relocation usually takes place on a voluntary basis [34].

The Bavarian state has decisive power in the planning process and reconstruction of the risk mitigation scheme for the Simbach torrent. The Simbach is a developed torrent in the city center and, consequently, the financial funding of maintenance and construction is on the state. Immediate financial aid for renovation of damages on private properties or public infrastructure was provided directly after the disaster. A subsidiarity fund of the European Union also supported the (re-) constructions. The local authority did not contribute to the relocation costs and financial buyouts. For affected residents, the compensation payment was relevant with regard to the relocation decision. Compensation payments were calculated based on " [... ] the market value before the damage. That's a 'mean' between the actual value after the flood damage and the reconstruction value, money that is needed to reconstruct the building as it was before damage" (Interview 5, 2018). The appraisal of the damaged houses was done by an independent expert, and most of the people were satisfied about the offered amount of money.

The relocation of 11 households and the buyout of further parts of land slots in Simbach were due to the need for space for the improved flood risk reduction scheme. Thus, the increased protection level according to the 1:100 floodwater discharge (as a mandatory value for the necessary protection level) mainly determined the area requirement for the structural measures. Thus, it was evident to the WMA Deggendorf at the very beginning that some of the properties near the river would have 
to be removed. While this decision was made intuitively and in a small team at the WMA, it was mainly based on the previous experience and professional expertise of the involved employees of the agency. In addition, most of the buildings of relocated residents were "totally or nearly totally destroyed" (Interview 2, 2018) and there was no option to rebuild on some of the land slots along the torrent. Responsible employees of the WMA communicated, in an early stage of the planning process, which properties would need to be given way, and some residents were only approached some days after the event. The area demand was even enlarged during the ongoing planning process, which was based on recalculations of the discharge value. Consequently, the height and size of the technical structures were adapted resulting in further land slots being affected. Financial compensation was calculated with the help of a "public, independent, state-appointed appraiser" (Interview 5, 2018), who was engaged to assess the buildings. The estimated amount of the money was based on "the market value before the damage. That is a 'mean' between the actual value after the flood damage and the reconstruction value, money that is needed to reconstruct the building as it was before the damage" (Interview 5, 2018). However, selling off the land and properties took place on voluntary basis and was announced early. "The WMA already stated directly after the event that some of the houses are not supposed to be renovated. The WMA contacted the affected property owners, and suggested them not to renovate the house, as they plan to make an offer for compensation payment based on the value before the event [ ... ]. Those houses were valued by an independent appraiser and so [ ... ] it was possible to purchase the needed properties without any coercive measures like expropriation" (Interview 5, 2018). The main actor for the property and land purchase was the WMA. The appraiser and the employees of the WMA communicating the buyout offer were described as playing a significant role from the perspective of the residents. Also, the compensation payment influenced the buyout decisions positively. These components contributed to a successful process. In accordance with funding regulations of the government and in collaboration with the city administration and with the property owners, the purchase and relocation were effectively conducted.

\subsection{Participation and Involvement in the Planned Relocation Process}

Participation of stakeholders and the general public including the affected residents in the overall planning process occurred at an early stage; citizens were offered to take part in informal assemblies, expert workshops, and individual meetings with local actors. The opportunity to ask questions and communicate ideas was given during five citizen assemblies and local workshops with experts of particular policy fields (urban and landscape planners, public infrastructure, business). This enabled the community to contribute to the planning process as knowledge was provided and questions were competently answered. Nonetheless, mistrust and doubts from the community about appropriate means for protection were stated in particular during initial meetings, which, however, could be promptly resolved by technical experts providing detailed explanation and delivering scientific facts. Despite the structural risk mitigation concept being elaborated by the responsible water management agency, public participation was restricted within this planning process. While being informed about the relocation issue from the beginning, the general public had the possibility to give feedback and input only at a later stage where the draft for the flood alleviation scheme was already elaborated. Participative planning such as developing technical concepts and ideas together with citizens was not possible according to planning experts. Therefore, integration of individual ideas was promoted, but considered as tough with respect to the technical planning process, as "too many cooks spoil the broth" (Interview 5, 2018). It was mentioned that more input of different stakeholders does not necessarily contribute to a better outcome since planning processes are complex and difficult to handle. However, the offered time for individual talks by the WMA experts was appreciated, and residents perceived the opportunity to participate as an "exciting collaboration in the community" (Interview 7, 2018).

The intention to purchase the properties and land by the WMA from the affected people started only some days after the event. Insurance agencies and independent appraisers were part of the process as their duty was the appraisal of the property for the financial compensation. Professionals from the WMAs real estate department were supposed to have sufficient experience and social skills to 
propose offers to the residents. This interaction with the property owners was a sensitive matter and required respect and patience, in particular in the case of elderly people or more severely affected cases. Individual discourse was necessary to clarify single issues in consideration of the property. Nonetheless, one-half of the flood victims accepted the offer immediately after the proposal by the WMA employee, who "[ ... ] showed them the expert reports with the amount of compensation money and, when they left the property, they saw the people dancing [ . . ] so those people were definitely happy." (Interview 5, 2018). In general, there was no time limit set for the final decisions. Such a buyout process could last several years; one resident reported that the appraiser already turned up for assessment two days after the event, while a year passed before getting a financial offer, and another few months went by until the money arrived in the bank account (Interview 6, 2018). Profound negotiations about the calculated property price were not possible and it was emphasized that "it is better to have a third party for doing that job because there are no possibilities for negotiations" (Interview 3, 2018). There was room to express and address individual needs (regarding details like a stairway to the water, visual protection, walls, etc.). Finally, some consensual efforts-with regard to single concerns about the selling of the property and land-were reached. Finding a consensus during discussions about individual details and concerns was, therefore, an integral part of the process. The appraiser was perceived as being a commissioner of the WMA, and trust encouraged a fair relationship between those parties. In addition, the mayor and the city administration, which did not have any executive power, played significant roles for the community, by acting as mediators or providing (new) information. Direct communication with residents was important, and "open doors at the city hall" (Interview 3, 2018) or weekly consultancy hours were used to talk about concerns, to ask questions, and to obtain general information. Regarding the early involvement of the residents and, consequently, the relocation, the point of time to suggest the buyout offer to the residents was considered as "just right" (Interview 5, 2018). However, for some citizens, the request about the intention to sell their property was considered to happen too early as the independent appraiser and the insurance showed up at the destroyed property already in the first week after the event. At this time point, some residents were not yet allowed to go back to their houses and properties as they were not accessible and closed down completely. While media such as newspaper served as a tool to inform the general public, the non-governmental agency Red Cross offered psychological support directly after the event in the form of individual consultation for traumatized flood victims up until two years after the event.

Finally, the collaboration between the stakeholders such as planners, scientists, and local actors took place at an equal level. Additionally, individual discourse and discussions about personal concerns were part of the integration of the public. A transparent planning process openly discussed and presented planning concepts, and an already given high flood risk awareness in the community provided a good basis for cooperation amongst main actors and the community.

\section{Discussions and Conclusions}

Natural hazards risk management is especially challenging when it comes to relocation of residents and area buyouts. While international and national legislations suggest the involvement of citizens in risk management, this is a pre-requisite for acceptance of planning decisions in the community and a successful implementation. Relocation as a precautionary measure is still rarely applied, although it might be indispensable in light of increased weather extremes and environmental change-triggering more natural hazards and economic damage. While sufficient time for in-depth planning after an event is critical, the necessity for being prepared to react to such hazards by prompt actions that need to be taken by decision-makers after extreme events is emphasized [13,58,73]. In Simbach, the relocation and the construction of the improved flood defense structures were implemented successfully. The approach in Simbach did not include a preliminary developed idea for the worst-case scenario (like extreme event and overload case), which could be of major use in the future to prevent catastrophes. The size of the area needed for structural measures was rather spontaneously determined than rationally chosen, based on former experience of the responsible actors. According to law, selling 
off the land and properties took place on a voluntary basis, whereas expropriation would have been a legal opportunity. The financial offer for compensation was accepted by most of the affected residents within some days. This was eventually amplified by the encouraged understanding of the enlarged structural measures combined with a new recreational area for the community along the channel. Nonetheless, relocation is complex and involves social and economic factors. The collaboration of stakeholders from the supra-national, national, regional, and local levels, as well as from policy fields such as water management, land use, or insurance, is demanded from the beginning. At the same time, the genuine involvement of the community and the consideration of its concerns are critical [34]. In the ideal case, this can be realized by a precautionary planning process and preventive actions before a damaging flood event occurs, and it might be increasingly demanded from future risk management.

\subsection{Perspective at the Regional Level}

While the Bavarian state had the overall authority in financial concerns, the WMA Deggendorf had the main planning responsibility in Simbach. Scientific facts and calculations were, therefore, the basis for the risk mitigation scheme planned by the WMA, together with experts of the University of Natural Resources and Life Sciences (BOKU). The LfU played a role as consultant in technical requests. However, the concept was implemented by planning authorities following a top-down perspective, as seen in the findings of Thaler and Hartmann [74]. Although close collaboration of governmental and non-governmental actors and sharing goals and expectations is crucial in a governance approach [40], these aspects were only partly considered in the investigated case. Shifting responsibility to individuals and corporate sectors is further recommended. A recent policy change in the Bavarian governmental financial damage funding after flood events deals exactly with this responsibility sharing. Since July 2019, there is no more public money available if the damage on the property is insurable by natural hazard insurance [75]. This is an attempt to avoid the "charity hazard phenomenon", which assumes that state funding diminishes the motivation to get private insurance for elementary loss, as people rely on governmental subsidies in the case of damage. However, natural hazard insurance should be increasingly applied, as long as it is affordable and reasonable.

Importantly, sufficient opportunities for participation for the affected community should be provided [37]. Despite the trend to implement improved mitigation concepts post occurrence [27], the elaboration of preliminary plans and having a strategy available in the early stage of the disaster aftermath could help to anticipate crisis after the event. Instead of "unplanned or reactive adaptation" and, consequently, the implementation of disaster-driven measures after a flood event, it is important that policy-makers recognize "signals" prior to natural hazards and accordingly "be able to take a more proactive and strategic approach" (p. 14) [48]. Thus, climate change adaptation regarding FRM needs to involve timely planning and integrated spatial planning visions, and this will be even more important in the future considering climate prospects.

While governmental decisions were made by authorities promptly after the event and criteria such as sufficient preparation time for a proper relocation process might have been insufficiently considered, the implementation of the plans was successful; the risk mitigation strategy, the increased area need, and the relocations for the adapted structural protection were supported and respected in the community. The early announcement about needed land slots, as well as the severe damage of some houses after the event, might have influenced the positive outcome of the process.

\subsection{Perspective at the Local Level}

Revised thinking of authorities and learning based on increased knowledge and scientific facts during the planning process contributed to the successful implementation of risk mitigation measures and the acceptance of household relocation. This was not only achieved by collaboration and trust in local politicians, but also because of the severity of the event and future climate prospects. Improved flood risk mitigation was successfully implemented during the post-event window of opportunity in Simbach; the chance to design a new recreational area for the community was used 
after the horrendous event, and the relocation was regarded as appropriate and on time. In addition, another phenomenon - the so-called "short memory syndrome" [76]—was observed. While people quickly forget about consequences and damages after severe events, they also tend to trivialize flood experience after a certain time passes. Therefore, this phenomenon promotes a quick start of planning and implementation of mitigation measures directly after a damaging event. At this stage, state funding is supposed to be more likely available, and measures are considered more reasonable [76]. Hence, relocation in Simbach was also accepted because of the communities' understanding for increased protection.

\subsection{Perspective of Citizens}

The local authority was involved in the process since the beginning, and affected residents were informed early about the consequences of the event. Residents also decided independently about their relocation. Therefore, not only the early announcement but also individual discourse with and trust in local actors was helpful [77]. Furthermore, the offered compensation payment influenced the buyout decisions. During the planning process for the structural measures, individual needs and concerns were addressed, although the integration of ideas in the technical concept and negotiations on the fixed compensation payment was limited. Nevertheless, finding consensus during individual discourse [77] was an essential part of the process, requiring mutual understanding.

In Simbach, there were limited options and barriers to seriously contribute to the decision-making process. Being involved at an early stage was important for the residents affected by the relocation process, although the effort and stage of the planning process can limit the involvement [78]. According to the idea of collaborative governance, stakeholder and public engagement was linked to the availability of resources [79] such as time, interest, and knowledge. Specialized knowledge [80] refers to technical expertise, which is required to understand the drafts of the designed constructions. Documents and presentations for the structural protection scheme were made available (online) by executive planners to increase understanding. While provision of information is a prerequisite for involvement, it was encouraged to individually take a closer look at the planning documents to get better insight into the process (Observation, 2018). However, professionals and experts offered opportunities to explain and support the capacity to grasp complex results and technical data. Nonetheless, it was stated that is difficult to integrate laymen's input in professional concepts. Knowledge was rather involved in the form of scientific facts and historical experience than by contributions of the local community-although local knowledge is considered as a valuable component in risk management [81]. Time on the citizens' behalf was relevant with respect to the stage of involvement and having available time to participate in the process. In particular, after the relocation, the lack of time, concern, and interest was the given reasons for not attending the assemblies (Interview 6, 2018). Furthermore, individual precaution and risk perception influence the willingness to participate in the decision-making process and to overtake responsibility [82]. Trust was enhanced by provided knowledge, scientific facts, and individual dialogue, while legitimacy and understanding of the mitigation concept was supported [79]. However, the open and direct communication with residents, the provision of information, and knowledge sharing during the assemblies showed attempts to let the community be part of the planning process. These factors were considered as key components for involvement in the risk management process.

The main lesson learned was that cooperation and collaboration in the form of common goals and a mutual understanding amongst all actors, stakeholders, and the civil society led to a positive process and a desired policy outcome in the Simbach case despite a top-down approach. The early integration of and a fair dialogue at an eye level with (affected) citizens provided possibilities to deal with individual needs and concerns, as well as increasing the acceptance of the process outcome. Additionally, the payment offers were crucial from the perspective of the residents. Personal talks, knowledge provision, and "open doors" for questions and input were important for Simbach residents to cope with the consequences of the flood event. A good relationship between the local authority and 
citizens provided a common basis for a successful policy process. Reliability and trust were assigned to public officials like the mayor, which was found helpful in terms of the positive outcome.

The small-scale relocation in Simbach followed a major flood event that claimed five fatalities and severe damage. The community and the administrative staff were not only personally affected during the disaster. Their professional life was also partly impacted during the recovery and reconstruction phase. Personal involvement and knowledge about the past events increased sensitivity in the negotiations and the overall procedure, which makes Simbach a good example for a collaborative planning and relocation process.

Author Contributions: Conceptualization, B.M. and J.H.; data curation, B.M.; formal analysis, B.M.; investigation, B.M.; methodology, B.M. and T.T.; project administration, B.M.; resources, B.M.; supervision, T.T. and J.H.; validation, B.M.; writing — original draft, B.M.; writing—review and editing, B.M. and T.T. All authors have read and agreed to the published version of the manuscript.

Funding: The funders had no role in the design of the study; in the collection, analyses, or interpretation of data; in the writing of the manuscript, or in the decision to publish the results. T.T. was funded by the Austrian Climate and Energy Fund for financing the RELOCATE2016-2018 project (grant number: B567142). The open access publication was supported by the BOKU Vienna Open Access Publishing Fund.

Conflicts of Interest: The authors declare no conflicts of interest.

\section{Appendix A}

\section{Acts and Regulations in German Water and Risk Management}

The laws and regulations listed below deal with water and FRM in Germany and Bavaria. Further below, the main regulations are described.

- $\quad$ Federal Water Act 2009 (Bavarian Federal Water Act 2010);

- German Spatial Planning Act 2008 (Bavarian Federal Planning Act 2005 and Regional Development Plan Bavaria 2006) including Priority and Reserve Areas with restricted use;

- German Building Code 2017 (Local Land Use Plan and Zoning Plan) containing regulations about restrictions in land use based on $\S 76$ of FWA 2009;

- Emergency management and civil protection.

The Federal Water Act 2009 (FWA) is the main national act for water management in Germany. It promotes sustainable management of groundwater bodies and surface waters including aspects of environmental protection, future climate change consequences, and interactions with other disciplines [46]. Whereas any activities causing negative impact on surface waters are to be avoided, the commitment to prevent flood damages by appropriate and adapted land use in consideration of potential flood events is an issue. Section 6 (§72-78) deals with flood risk alleviation; main subjects are risk assessment, as well as the establishment of hazard and flood risk maps and risk management plans. Inundation areas are calculated on a 100-year flood event, and responsibilities for maintenance and development of waterways, as well as guidelines for legal and administrative planning procedures, are depicted in the law. It also hints at active involvement of citizens in flood risk mitigation and assessment [46].

The Bavarian Federal Water Act 2010 comprises the implementation of the German Water Act at the state level [83]. It contains details for risk management procedures and defines responsibilities for the construction of flood protection measures including maintenance tasks and funding aspects. State ministries and affected municipalities are involved in risk assessment and management processes, while the Bavarian Environment Agency and the Water Management Agencies (WMAs) are technical consultants [83]. The main authority responsible for waterways of third order (including rivers with "torrent-specific characteristics" (in German: "In das Verzeichnis der Wildbäche sind die Gewässer dritter Ordnung einzutragen, die zumindest streckenweise wildbachtypische Eigenschaften aufweisen" (p. 2) [83])) is the communal authority, for example, a municipality or a city. If the torrent is partly 
developed, the Bavarian State shares responsibility [83]. Thus, inundation areas are assessed by these responsible authorities together with the administrative Water Management Agencies, who are assigned to water districts in the federal state. In this way, simulations and calculations of a 100-year flood event (HQ100) offer the possibility to determine inundation areas. Therefore, torrent-specific characteristics of the rivers need to be considered and, if the calculation of the flood-prone area is too much effort, the area demand for inundation zones "can be estimated on appropriate height measurements and former flood events" (p. 16) [83]. Inundation areas are then dedicated by the responsible district administration authority and published in the journal of the district office and of the county before enacting. Citizen involvement in such decisions is legally prescribed; hence, people can give input to these drafts which need to be integrated by administrative authorities [72]. The Bavarian Water Law also provides legal tools such as expropriation, in cases of area needs for mitigation measures. Pre-emptive purchase rights are, thus, assigned to the government. Responsible authorities together with the LfU handle this risk management process, while compensation payment in the case of expropriation is foreseen. Inclusion of private experts is also proclaimed in the water act [83].

The German Spatial Planning Act (ROG) deals with sustainable land management on a national level and depicts the main goals of regional planning visions. The Bavarian Federal Planning Act 2005 and the Regional Development Plan of Bavaria 2006 are documents for actions taken at a state level. Friesecke (2004) specified four levels in spatial planning in Germany: federation (spatial planning at federal level), laender (corresponding to federal states; state planning), region (regional planning), and municipalities (local planning). Regional plans are legally binding; consequently, local regulations have to be in line with and implement restrictions accordingly [84]. The actual version of the ROG (2008) comprises "dedicated areas for precautionary flood protection" ("Freiräume zur Gewährleistung des vorbeugenden Hochwasserschutzes" (p. 14) [85]. Supplement: "(7) Die Festlegungen [ . . ] können auch Gebiete bezeichnen, 2. in denen bestimmten raumbedeutsamen Funktionen oder Nutzungen bei der Abwägung mit konkurrierenden raumbedeutsamen Nutzungen besonderes Gewicht beizumessen ist (Vorbehaltsgebiete)" (p. 15) [85]) [85], whereas inundation areas are determined as "all areas that are actually inundated at a significant flood event (in general a HQ100)". Based on the Spatial Planning Act, priority and reserve areas have to be kept free from buildings, while the exposure to flood risk and inundation has to be obvious in local development plans $[85,86]$. Main goals are the sufficient restriction of further residential developments in affected areas, land reclaim for relocation of dykes, and restoration of former retention areas [86].

The German Building Code 2017 contains prescriptions for the establishment of regional land-use plans and zoning plans by municipalities on local levels. Hence, those documents promote a sustainable urban planning vision, while it is essential that they are aligned with spatial development goals. Inundation and at-risk areas have to be implemented and highlighted in land-use plans according to the Federal Water Act $(\$ 76,78)$ [87]. Consequently, legal restrictions in dedicated zones can affect local land use and building activities. Nonetheless, exceptions were made and residential developments in flood-prone areas were developed. Data about the amount of dedicated building areas in flood risk zones defined by municipalities in Bavaria are not available, and there is a lack of information about actual building activities by communities in such zones [72]. The information service about inundation areas and flood risk publishes interactive online available maps, which provide an overview of risk areas at a scale of 1:10,000 [49].

\section{References}

1. World Economic Forum. The Global Risks Report 2019_Insight Report; World Economic Forum: Geneva, Switzerland, 2019; Available online: http://wef.ch/risks2019 (accessed on 15 October 2019).

2. Munich Re. Münchener Rückversicherungs-Gesellschaft Aktiengesellschaft. 2019. Available online: www.munichre.com (accessed on 16 October 2019). 
3. European Environmental Agency. Mapping the impacts of natural hazards and technological accidents in Europe An overview of the last decade. 2010. Available online: www.eea.europa.eu (accessed on 15 October 2019).

4. Die Allianz Deutschland, AG. Elementarversicherung. 2018. Available online: https://www.allianz.de/rechtund-eigentum/wohngebaeudeversicherung/elementarversicherung/ (accessed on 15 Oktober 2019).

5. Fuchs, S.; Röthlisberger, V.; Thaler, T.; Zischg, A.; Keiler, M. Natural hazard management from a coevolutionary perspective: Exposure and policy response in the European alps. Ann. Am. Assoc. Geogr. 2017, 107, 382-392. [CrossRef] [PubMed]

6. Ferguson, A.P.; Ashley, W.S. Spatiotemporal analysis of residential flood exposure in the Atlanta, Georgia metropolitan area. Nat. Hazards 2017, 87, 989-1016. [CrossRef]

7. Tate, E.; Strong, A.; Kraus, T.; Xiong, H. Flood recovery and property acquisition in Cedar Rapids, Iowa. Nat. Hazards 2016, 80, 2055-2079. [CrossRef]

8. King, D.; Bird, D.; Haynes, K.; Boon, H.; Cottrell, A.; Millar, J.; Okada, T.; Box, P.; Keogh, D.; Thomas, M. Voluntary relocation as an adaptation strategy to extreme weather events. Int. J. Dis. Risk Reduct. 2014, 8, 83-90. [CrossRef]

9. Thaler, T.; Fuchs, S. Financial recovery schemes in Austria: How planned relocation is used as an answer to future flood events. Environ. Hazards 2019, 1-17. [CrossRef]

10. Perry, R.W.; Lindell, M.K. Principles for managing community relocation as a hazard mitigation measure. J. Conting. Crisis Manag. 1997, 5, 49-59. [CrossRef]

11. Orlove, B. Human adaptation to climate change: A review of three historical cases and some general perspectives. Environ. Sci. Policy 2005, 8, 589-600. [CrossRef]

12. Miller, F. Exploring the consequences of climate-related displacement for just resilience in Vietnam. Urban Stud. 2019. [CrossRef]

13. Mortreux, C.; de Campos, R.S.; Adger, W.N.; Ghosh, T.; Das, S.; Adams, H.; Hazra, S. Political economy of planned relocation: A model of action and inaction in government responses. Glob. Environ. Chang. 2018, 50, 123-132. [CrossRef]

14. McLeman, R.; Smit, B. Migration as an adaptation to climate change. Clim. Chang. 2006, 76, 31-53. [CrossRef]

15. Hurlimann, A.; Dolnicar, S. Voluntary relocation-An exploration of Australian attitudes in the context of drought, recycled and desalinated water. Glob. Environ. Chang. 2011, 21, 1084-1094. [CrossRef]

16. Bukvic, A. Integrated framework for the Relocation Potential Assessment of Coastal Communities (RPACC): Application to Hurricane Sandy-affected areas. Environ. Syst. Decis. 2015, 35, 264-278. [CrossRef]

17. Bukvic, A. Identifying gaps and inconsistencies in the use of relocation rhetoric: A prerequisite for sound relocation policy and planning. Mitig. Adapt. Strateg. Glob. Chang. 2015, 20, 1203-1209. [CrossRef]

18. Worldbank. Groundswell: Preparing for internal climate migration. 2018. Available online: https://www.worldbank.org/en/news/infographic/2018/03/19/groundswell---preparing-for-internalclimate-migration (accessed on 10 October 2019).

19. Hino, M.; Field, C.B.; Mach, K.J. Managed retreat as a response to natural hazard risk. Nat. Clim. Chang. 2017, 7, 364-370. [CrossRef]

20. European Commission. Directive 2007/60/EC of the European Parliament and of the Council of 23 October 2007 on the assessment and management of flood risks. Off. J. Eur. Parliam. 2007, 288, 27-34. Available online: http://eur-lex.europa.eu/legal-content/EN/TXT/PDF/?uri=CELEX:32007L0060\&from=EN (accessed on 10 October 2019).

21. Directive, W.F. 2000/60/EC of the european parliament and of the council of 23 October 2000 establishing a framework for Community action in the field of water policy. Off. J. Eur. Commun. 2000, 327, 1-72. Available online: https://eur-lex.europa.eu/eli/dir/2000/60/oj (accessed on 10 October 2019).

22. Hübl, J. Das Hochwasserereignis am Simbach im Sommer 2016. In Naturgefahren-Von der Sturzflut zur Schwemmholzverklausung Ereignisanalysen, aktuelle Forschungsvorhaben und Projekte; Rutschmann, P., Ed.; Quelle: München, Germany, 2017; pp. 13-24.

23. Jekel, H.; Arle, J.; Bartel, H.; Baumgarten, C.; Blondzik, K.; Claussen, U.; Damian, H.P.; Döscher, K.; Dubbert, W.; Eggers, H.-H.; et al. Water Resource Management in Germany-Part 1 Fundamentals; Bundesministerium für Umwelt, Naturschutz, Bau und Reaktorsicherheit: Bonn, Germany, 2013; Available online: http: //www.umweltbundesamt.de/publikationen/water-resource-management-in-germany-part-1 (accessed on 9 October 2019). 
24. Dieperink, C.; Hegger, D.L.T.; Bakker, M.H.N.; Kundzewicz, Z.W.; Green, C.; Driessen, P.P.J. Recurrent governance challenges in the implementation and alignment of flood risk management strategies: A review. Water Resour. Manag. 2016, 30, 4467-4481. [CrossRef]

25. Hartmann, T.; Albrecht, J. From flood protection to flood risk management: Condition-based and performance-based regulations in German Water Law. J. Environ. Law 2014, 26, 243-268. [CrossRef]

26. Kundzewicz, Z.W. Non-structural flood protection and sustainability. Water Int. 2002, 27, 3-13. [CrossRef]

27. Kreibich, H.; Di Baldassarre, G.; Vorogushyn, S.; Aerts, J.C.; Apel, H.; Aronica, G.T.; Arnbjerg-Nielsen, K.; Bouwer, L.M.; Bubeck, P.; Caloiero, T.; et al. Adaptation to flood risk: Results of international paired flood event studies. Earth's Future 2017, 5, 953-965. [CrossRef]

28. Rauter, M.; Thaler, T.; Attems, M.S.; Fuchs, S. Obligation or innovation: Can the EU Floods Directive be seen as a tipping point towards more resilient flood risk management? Case Study Vorarlb. Austria Sustain. 2019, 11, 5505. [CrossRef]

29. Pichler, A.; Deppe, T.; Jackson, V. CRUE Research funding initiative addressing the key findings of research: Efficiency of non-structural flood risk management measures. 2009. Available online: http: //www.crue-eranet.net/publications.asp (accessed on 8 October 2019).

30. Brookings Institute; Georgetown University; UNHCR The UN Refugee Agency. Guidance on protecting people from disasters and enviornmental change through planned relocation. 2015, pp. 1-22. Available online: https://www.unhcr.org/protection/environment/562f798d9/planned-relocation-guidance-october2015.html (accessed on 6 October 2019).

31. Binder, S.B.; Baker, C.K.; Barile, J.P. Rebuild or relocate? Resilience and postdisaster decision-making after Hurricane Sandy. Am. J. Community Psychol. 2015, 56, 180-196. [CrossRef] [PubMed]

32. Binder, S.B.; Barile, J.P.; Baker, C.K.; Kulp, B. Home buyouts and household recovery: Neighborhood differences three years after Hurricane Sandy. Environ. Hazards. 2019, 18, 127-145. [CrossRef]

33. Siders, A.R. Social justice implications of US managed retreat buyout programs. Clim. Chang. 2019, 152, 239-257. [CrossRef]

34. Schindelegger, A. Relocation for flood retention in Austria. In Opportunities and Constraints of Land Management in Local and Regional Development: Integrated Knowledge, Factors and Trade-Offs; Vdf Hochschulverlag AG an der ETH Zürich: Zürich, Switzerland, 2018; pp. 111-121.

35. Sipe, N.; Vella, K. Relocating a flood-affected community: Good planning or good politics? J. Am. Plan. Assoc. 2014, 80, 400-412. [CrossRef]

36. BMLFUW. FloodRisk II Vertiefung und Vernetzung zukunftsweisender Umsetzungsstrategien zum integrierten Hochwasserschutz; BMLFUW: Wien, Austria, 2009; Available online: https://www.bmvit.gv.at/service/ publikationen/verkehr/schifffahrt/downloads/floodrisk.pdf (accessed on 10 October 2019).

37. Seebauer, S.; Thaler, T.; Schindelegger, A.; Wenk, M. Gestaltung von privater Absiedlung aus Hochwasser-Risikogebieten: Handbuch für Entscheidungsträgerinnen und -träger. 2018. Available online: https://www.researchgate.net/publication/323735039_Gestaltung_von_privater_Absiedlung_ aus_Hochwasser-Risikogebieten_Handbuch_fur_Entscheidungstragerinnen_und_-trager (accessed on 3 January 2020).

38. Stoker, G. No Governance as theory: Five propositions. Int. Soc. Sci. J. 1998, 50, 17-28. [CrossRef]

39. Rhodes, R.A.W. The new governance: Governing without government. Political Stud. 1996, 44, $652-667$. [CrossRef]

40. Ansell, C.; Gash, A. Collaborative governance in theory and practice. J. Public Adm. Res. Theory 2008, 18, 543-571. [CrossRef]

41. Alexander, M.; Priest, S.; Mees, H. A framework for evaluating flood risk governance. Environ. Sci. Policy 2016, 64, 38-47. [CrossRef]

42. Bayerisches Staatsministerium für Umwelt und Verbraucherschutz. Hochwasserschutz Aktionsprogramm 2020plus; Bayerisches Staatsministerium für Umwelt und Verbraucherschutz: München, Germany, 2014; p. 50. Available online: https://stmuv.bayern.de/themen/wasserwirtschaft/hochwasser/index.htm (accessed on 10 October 2019).

43. Renn, O.; Schweizer, P.J. Inclusive risk governance: Concepts and application to environmental policy making. Environ. Policy Gov. 2009, 19, 174-185. [CrossRef] 
44. Habersack, H.; Schober, B.; Bürgel, J.; Kanonier, A. Floodrisk-E(valuierung) Analyse der Empfehlungen aus FRI und II und deren Umsetzungsfortschritt im Lichte der Umsetzung der Hochwasserrichtlinie Synthesebericht. Umwelt und Wasserwirtschaft 2015, 103.

45. King, D. Why move back? Floods and the difficulty of relocation. The Conversation. 2013, p. 4. Available online: https://theconversation.com/why-move-back-floods-and-the-difficulty-of-relocation-11884 (accessed on 9 October 2019).

46. Bundesministerium der Justiz und für Verbraucherschutz. Gesetz zur Ordnung des Wasserhaushalts (Wasserhaushaltsgesetz-WHG); Bundesministerium der Justiz und für Verbraucherschutz: Berlin, Germany, 2009.

47. Baier, J.; Benton, G.; Bergman, J.; Blocher, J.; Bower, E.; Bronen, R.; Burkett, M.; Corendea, C.; Correa, E.; Ferris, E.; et al. A Toolbox: Planning Relocations to Protect People from Disasters and Environmental Change; International Organization for Migration: Geneva, Switzerland, 2016.

48. Penning-Rowsell, E.; Johnson, C.; Tunstall, S. 'Signals' from pre-crisis discourse: Lessons from UK flooding for global environmental policy change? Glob. Environ. Chang. 2006, 16, 323-339. [CrossRef]

49. LfU Bayerisches Landesamt für Umwelt. Website des Bayerisches Landesamt für Umwelt. 2018. Available online: https://www.lfu.bayern.de/wasser/wrrl/bewirtschaftungsplaene_1015/doc/donau_bp_ 2009_ohneanhang.pdf (accessed on 12 October 2019).

50. Findl, R.; Brodschelm, T.; Geiring, W. Das Jahrtausendhochwasser Simbach am Inn-1. Juni 2016; Stadt Simbach: Simbach am Inn, Germany, 2017.

51. Otto, G. Hochwasser in Simbach am Inn. In Das Jahrtausendhochwasser Simbach am Inn-1 Juni 2016; Stadt Simbach: Simbach am Inn, Germany, 2017; pp. 162-163.

52. Findl, R. Simbach soll sein Gesicht behalten. In Das Jahrtausendhochwasser Simbach am Inn-1 Juni 2016; Stadt Simbach: Simbach am Inn, Germany, 2017; p. 165.

53. Otto, G. Der Inn und sein Überschwemmungsgebiet. In Das Jahrtausendhochwasser Simbach am Inn-1 Juni 2016; Stadt Simbach: Simbach am Inn, Germany, 2017; pp. 157-161.

54. Stadt Simbach am Inn. Stadt Simbach a. Inn Zahlen-Daten-Fakten; Simbach am Inn: Simbach am Inn, Germany, 2018; pp. 1-14. Available online: http://www.simbach.de/images/pdf/ZAHLENDA.pdf?artikel_id=\&liste= \&tmpl_typ $=\& l p=1928 \& a r e a=100$ (accessed on 10 October 2019).

55. Hübl, J.; Heiser, M.; Braito, S.; Tscharner, S.; Kuntner, K.; Prenner, D.; Falkensteiner, M.; Rabanser, E. Ereignisdokumentation und Ereignisanalyse 2016 Rottal-Inn, IAN Report 180, Band 2: Ereignisanalyse Simbach; Universität für Bodenkultur Wien, Department Bautechnik und Naturgefahren, Institut für Alpine Naturgefahren: Vienna, Austria, 2017.

56. Hübl, J. Hochwasser Simbach 2016: Dokumentation und Analyse. Wasserwirtschaft 2017, 107, 61-64. [CrossRef]

57. Hübl, J.; Heiser, M.; Braito, S.; Tscharner, S.; Kuntner, K.; Schraml, K.; Falkensteiner, M.; Rabanser, E. Ereignisdokumentation und Ereignisanalyse 2016 Rottal-Inn, IAN Report 180, Band 1: Ereignisdokumentation; Universität für Bodenkultur Wien, Department Bautechnik und Naturgefahren, Institut für Alpine Naturgefahren: Vienna, Austria, 2017.

58. Rimböck, A.; Hübl, J.; Höhne, R. Extreme torrential flooding at Simbach on June 1st, 2016-Key findings of a detailed event analysis. In Proceedings of the Interpraenent 2018 in the Pacific Rim, Toyama, Japan, 1-4 October 2018; pp. 1-8.

59. Yin, R.K. Applications of Case Study Research, 3rd ed.; Sage Publications, Inc.: Thousand Oaks, CA, USA, 2012.

60. Yin, R.K. Case Study Research: Design and Methods, 2nd ed.; Foster, D.S., Ed.; Thousand Oaks London New Delhi Sage Publications, Inc.: Thousand Oaks, CA, USA, 1994.

61. Patton, M.Q. Two decades of developments in qualitative inquiry. Qual. Soc. Work Res. Pract. 2002, 1, 261-283. [CrossRef]

62. Stake, R.E. The Art of Case Study Research; Sage Publications, Inc.: Thousand Oaks, CA, USA, 1995.

63. Flyvbjerg, B. Five misunderstandings about case-study research. Qual. Inq. 2006, 12, 219-245. [CrossRef]

64. Goodman, L.A. Snowball sampling. Ann. Math. Stat. 1961, 32, 148-170. [CrossRef]

65. Cohen, N.; Arieli, T. Field research in conflict environments: Methodological challenges and snowball sampling. J. Peace Res. 2011, 48, 423-435. [CrossRef]

66. Corbin, J.; Strauss, A. Grounded Theory Research: Procedures, Canons, and Evaluative Criteria. Qual. Social. 1990, 13, 3-21. [CrossRef]

67. Kvale, S.; Brinkmann, S. Interviews Learning the Craft of Qualitative Research Interviewing, 2nd ed.; Sage Publications Inc.: Los Angeles, CA, USA; London, UK; New Delhi, India; Singapore, 2009. 
68. Strauss, A.L.; Glaser, B.G. Grounded Theory Strategien Qualitativer Forschung; Huber: Bern, Switzerland; Göttingen, Germany; Toronto, ON, Canada; Seattle, WA, USA, 1998.

69. Hübl, J.; Braito, S.; Bramberger, J.; Beck, M.; Heiser, M.; Kamper, S.; Nagl, G.; Wernhart, S. Schutzwasserbauliches Maßnahmenkonzept am Simbach, IAN Report 190; Universität für Bodenkultur Wien, Department Bautechnik und Naturgefahren, Institut für Alpine Naturgefahren: Vienna, Austria, 2017.

70. Wasserwirtschaftsamt Deggendorf. Wiederherstellung und Verbesserung des Hochwasserschutzes am Simbach; Sachstandsbericht im Rahmen der Bürgerversammlung am 07.11.2017; Wasserwirtschaftsamt Deggendorf: Deggendorf, Germany, 2017.

71. Wasserwirtschaftsamt Deggendorf. Hochwasserschutz Simbach am Inn Vorgeschichte und Ausbauziel Hochwasserschutzprojekt Simbach—Wasserwirtschaftsamt Deggendorf Terminplanung Finanzierung der Maßnahme; Wasserwirtschaftsamt Deggendorf: Deggendorf, Germany, 2017.

72. Müller, U. Bayerischer Landtag Schriftliche Anfrage; Bayerischer Landtag: München, Germany, 2014.

73. Seebauer, S.; Winkler, C. Should I stay or should I go? Factors in household decisions for or against relocation from a flood risk area. Glob. Environ. Chang. 2020, 60, 102018. [CrossRef]

74. Thaler, T.; Hartmann, T. Justice and flood risk management: Reflecting on different approaches to distribute and allocate flood risk management in Europe. Nat. Hazards 2016, 83, 129-147. [CrossRef]

75. Bayern Landesamt für Umwelt. Website Landesamt für Umwelt Bayern. 2017. Available online: https: //www.lfu.bayern.de (accessed on 10 October 2019).

76. Kundzewicz, Z.W.; Lugeri, N.; Dankers, R.; Hirabayashi, Y.; Döll, P.; Pińskwar, I.; Dysarz, T.; Hochrainer, S.; Matczak, P. Assessing river flood risk and adaptation in Europe-review of projections for the future. Mitig. Adapt. Strateg. Glob. Chang. 2010, 15, 641-656. [CrossRef]

77. Renn, O. Risk governance-Towards an integrative approach. In Handbook of Risk Theory: Epistemology, Decision Theory, Ethics, and Social Implications of Risk; Springer Nature: Basel, Switzerland, 2012.

78. Tseng, C.; Penning-Rowsell, E.C. Micro-political and related barriers to stakeholder engagement in flood risk management. Geogr. J. 2012, 178, 1-20. [CrossRef]

79. Emerson, K.; Nabatchi, T.; Balogh, S. An integrative framework for collaborative governance. J. Public Adm. Res. Theory 2012, 22, 1-29. [CrossRef]

80. Zadek, S. The Logic of collaborative governance. Corporate responsibility, accountability, and the social contract. Corp. Soc. Responsib. Initiat. 2006, 17, 1-30.

81. Becker, M. The Role of Intermediaries in flood risk management. In Oxford Research Encyclopedia of Natural Hazard Science; Oxford University Press: Oxford, UK, 2018.

82. Roos, M.M.D.; Hartmann, T.T.; Spit, T.T.J.M.; Johann, G.G. Constructing risks-Internalisation of flood risks in the flood risk management plan. Environ. Sci. Policy 2017, 74, 23-29. [CrossRef]

83. Landtag des Freistaates Bayern. Bayerisches Wassergesetz (BayWG) Vom 25. Februar 2010 (GVBl. S. 66) BayRS 753-1-U; Bayrische Staatskanzlei: München, Germany, 2010.

84. Friesecke, F. Precautionary and sustainable flood protection in Germany-Strategies and instruments of spatial planning. In Proceedings of the 3rd FIG Regional Conference, Jakarta, Indonesia, 3-7 October 2004; pp. 1-17.

85. Bundesrepublik Deutschland. Raumordnungsgesetzes (ROG) vom 22. Dezember 2008; Bayerisches Staatsministerium für Wirtschaft, Landesentwicklung und Energie: München, Germany, 2009; pp. 1-38. Available online: https://www.landesentwicklung-bayern.de/fileadmin/user_upload/landesentwicklung/ Dokumente_und_Cover/Rechtsgrundlagen/ROG.pdf (accessed on 11 October 2019).

86. Bundesministerium für Verkehr Bau- und Wohnungswesen. Handlungsempfehlungen der Ministerkonferenz für Raumordnung zum vorbeugenden Hochwasserschutz. 2000. Available online: https://www.umweltonline.de/recht/bau/howaz2000.htm (accessed on 10 October 2019).

87. Bundesministerium der Justiz und für Verbraucherschutz. Baugesetzbuch in der Fassung der Bekanntmachung vom 3. November 2017 (BGBl. I S. 3634); Bundesrepublik Deutschland: Berlin, Germany, 2017; pp. 1-118. Available online: https://www.gesetze-im-internet.de/bbaug/BauGB.pdf (accessed on 10 October 2019).

(C) 2020 by the authors. Licensee MDPI, Basel, Switzerland. This article is an open access article distributed under the terms and conditions of the Creative Commons Attribution (CC BY) license (http://creativecommons.org/licenses/by/4.0/). 